\title{
カンボジア農村部における小学生の食生活
}

\author{
白井睦子 $\cdot$ 高村一知
}

(安田女子大学家政学部管理栄養学科)

\section{Food Intake among Elementary School Students in a Rural Area of Cambodia}

\author{
Mutsuko Shirai, Kazunori Takamura \\ Department of Nutritional Sciences, Yasuda Women's University, 6-13-1 \\ Yasuhigashi, Asaminami-ku, Hiroshima, 731-0153, Japan \\ 干731-0153 広島県広島市安佐南区安東 6-13-1
}

\begin{abstract}
We investigated the food intake and physical condition among elementary school children in rural Cambodia during Feb-March 2006. Data were collected from 274 elementary school children (119 boys and 155 girls) aged $9-16$ years. The following results were obtained:

1) With regard to the frequency of dietary intake a day, $61 \%$ of the students had "three meals", but $39 \%$ of the students had "two meals". $79 \%$ of the students had the largest amount of daily meals at lunch. The frequency of protein-rich food intake, such as meat and dairy products was low.

2) The proportion of underweight children with respect to the Rohrer Index was $80 \%$ of all boys and $71 \%$ of all girls. Also, the weight and height of both boys and girls in rural Cambodia were lower than those of Japanese children of the same age. Moreover, there were many children who had answered, "normal" in the question about consciousness of their physiques, though they were thin.

The present results show that the nutritional status of elementary school children in rural Cambodia is inadequate. In conclusion, as it is important that children obtain a good nutritional status for their growth, the study recommends a comprehensive strategy to be implemented in rural Cambodia in order to prevent children from the undernourishment.
\end{abstract}

\section{緒言}

カンボジアでは1970年代から20年に渡って内戦が続き, 多くの人命が失われた1)。内戦終結後 10 年以上が経過し た現在では, 復興開発が進み, 教育面ではようやく小学 校などの公教育が正常化し始めている。しかし，働き手 の子どもを学校に通わせない親もおり，就学率は約 $80 \%$, 小学 6 年を卒業できるのは $48 \%$ と低い。

カンボジアの主要産業は農業であり, 稲作がその中心 である。都市部には大きな食糧市場がいくつもあり食材 は豊富に揃っている。しかし，農村部における食料事情 は都市部に比較して良くない。また経済面でも収入は低
く, 食生活面でも 1 日に食事を 3 回食べるのが困難な家 庭もある。そこで国連世界食糧計画 (The United Nations World Food Programme:WFP）支援の学校給食が 配給されている。学校給食は家庭内で充分な食事を受け ることができない児童に栄養価の高い食事を提供するだ けでなく, 就学率と学習能力を高め, 教育の機会を拡げ ることを目的としている。WFP の学校給食は週 5 回, 朝食のみであり, メニューは児童の最低限の栄養摂取を 目的としたニシンの缶詰スープと緑豆ご飯である。児童 の身体の成長と知能の発育には, 一定量のエネルギー摄 取とバランスの取れた栄養摂取が重要課題であるが, 給 食だけでは充分とは言えない。また, WFPの学校給食 
プログラムは 3 年間で終了予定である。

これまでにもカンボジアの伝統的な食文化を紹介する 文献2３）はあるが，食生活状況に関する調査研究はほと んど報告されていない。そこで, カンボジア北西部の農 村地帯にあるササースダム小学校の児童を対象に日常の 食生活と健康状態を把握するためにアンケート調査と身 体測定を行ったので報告する。

\section{方法}

\section{1. 調査時期および調査地域}

調査は2006年 2 月〜 3 月 (乾季) にカンボジア北西部 のシェムリアップ州プク郡のササースダムの農村地帯に あるササースダム小学校で行った（図 1 )。

\section{2. 調査対象}

調査対象者は 4 年生および 6 年生の小学生（ 9 歳〜 16 歳） 274 人（男子 119 人, 女子 155 人）で, 性別および年 齢構成を表 1 に示した。

\section{3 . 食生活調査方法}

食生活に関する調査項目は表 2 の通りで，アンケート
方式で行った。調査はクメール語による記述質問用紙を 配布後, クラス担任教員の説明に従って回答を得た。

\section{4. 身体測定}

食生活アンケート調査を行った同じ時期の2006年 2 月 〜 月に, 身体測定を行った。身長, 体重の測定は 4 年 生および 6 年生の小学生（ 9 歳 16歳） 265 人（男子 115 人，女子 150 人）を対象に行った。このうち食生活アン ケート調査と身体測定の両方を行ったのは254人（男子 105 人, 女子 149 人）で, 残りの 11 名（男子 10 名, 女子 1 名）は欠席者である。測定した身長および体重から学童 期の体格指標となるローレル指数 $=$ （体重 $(\mathrm{kg}) /$ 身 長 $\left.(\mathrm{cm})^{3}\right) \times 10^{7}$ を算出し, 体格の判定も行った。

\section{結 果}

\section{1. 家族構成}

家族構成についてのアンケート調査では, 家族の人数 は $5 \sim 8$ 人 $(72 \%)$ が多く, 平均 6.87 人, 兄弟姉妹の数 も $3 \sim 7$ 人 $(81 \%)$ が多く, 平均 5.18 人と日本の 1 世帯 当たりの平均世帯員数 2.68 人（2005年国勢調査結果）に
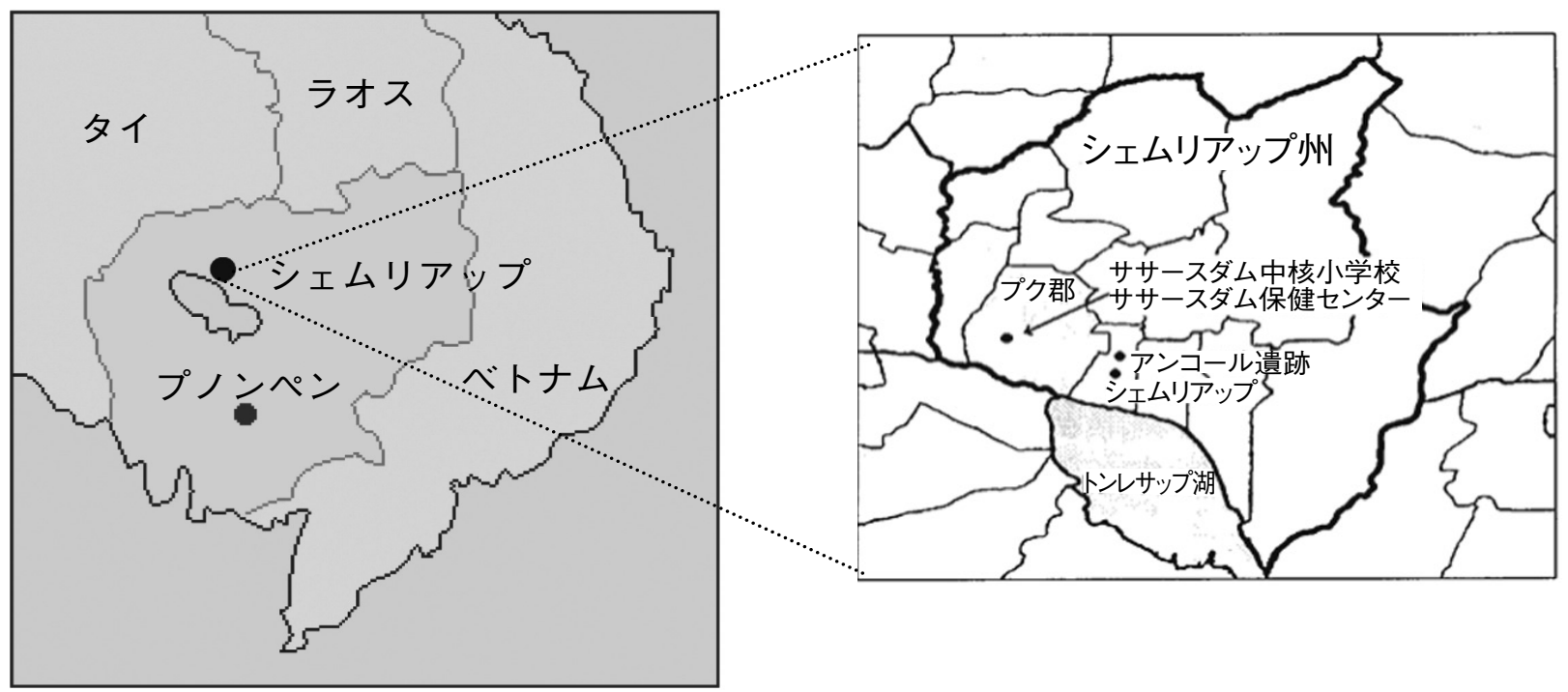

図 1 カンボジアと調査地域の地図

表 1 調査対象小学生の性別および年齢

\begin{tabular}{cccc}
\hline \multirow{2}{*}{ 年齢 } & \multicolumn{4}{c}{ 人 数 } \\
\cline { 2 - 4 } & 男 $(\%)$ & 女 $(\%)$ & 全体 $(\%)$ \\
\hline 9 歳 & $8(2.9)$ & $12(4.4)$ & $20(7.3)$ \\
10 歳 & $18(6.6)$ & $27(10.0)$ & $45(16.6)$ \\
11 歳 & $12(4.4)$ & $28(10.2)$ & $40(14.6)$ \\
12 歳 & $25(9.1)$ & $34(12.4)$ & $59(21.5)$ \\
13 歳 & $20(7.3)$ & $33(12.0)$ & $53(19.3)$ \\
14 歳 & $20(7.3)$ & $16(5.8)$ & $36(13.1)$ \\
15 歳 & $11(4.0)$ & $2(0.7)$ & $13(4.7)$ \\
16 歳 & $5(1.8)$ & $3(1.1)$ & $8(2.9)$ \\
\hline 計 & $119(43.4)$ & $155(56.6)$ & $274(100.0)$ \\
\hline
\end{tabular}


表 2 食生活アンケート調査項目

\begin{tabular}{|c|}
\hline 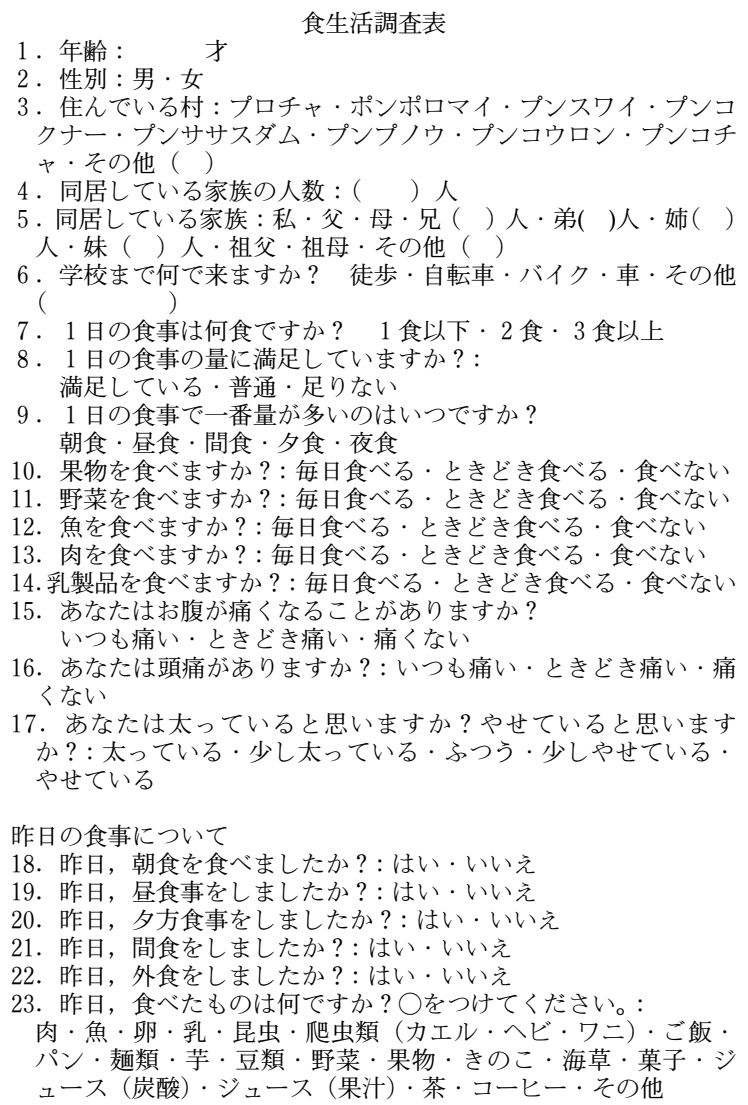 \\
\hline
\end{tabular}

昨日の活動について

24. 昨日，よく眠れましたか？:はい・いいえ

25. 昨日, 勉強をしましたか? : はい・いいえ

26. 昨日, 遊びをしたか? : はい・いいえ

27. 昨日，仕事をしましたか？：はい・いいえ

28. 昨日，運動をしましたか？：はい・いいえ

今の体調について

29. 食欲はありますか？：はい・いいえ

30. 今，あなたは下痢をしていますか？：はい・いいえ

31. 今，あなたは便秘をしていますか? : はい・いいえ

32. 今, あなたは虫歯がありますか? : はい・いいえ

33. あなたは健康だと思いますか？：はい.いいえ

給食がある日について

34. 給食を食べあすか？：毎日食べる・時々食べる・食べない

35. 給食の量はどうですか？：多い・普通・少ない

36. 給食は美味しいですか？：美味しい・普通・まずい

37. 給食が好きですか？：好き・普通・きらい

38. 給食の配給は必要だと思いますか？： 必要・必要ない・わからない

給食がない日について

39．朝食を食べすすか？：毎日食べる・時々食べる・食べない

40. どこで朝食を食べますか？： 家·マーケット・学校の売店·その他（）

41. 家の朝食の量はどうですか? : 多い.普通・少ない

42. 家の朝食の量は給食と比べてどうですか？：多い・同じ・少な

43. 家の朝食は美味しいですか? : 美味しい.普通・まずい

44. 家の朝食は給食と比べて美味しいですか？： 美味しい.普通・まずい

45. 家の朝食と給食はどちらがよいですか？： 家の朝食・どちらでもいい. 給食・わからない

表 3 家族構成

\begin{tabular}{|c|c|c|c|c|c|}
\hline 家族の人数 & 人数 & $(\%)$ & 兄弟姉妹の人数 & 人数 & $(\%)$ \\
\hline 2 人 & 2 & 0.7 & 1 人 & 2 & 0.7 \\
\hline 3 人 & 5 & 1.8 & 2 人 & 16 & 5.8 \\
\hline 4 人 & 19 & 6.9 & 3 人 & 45 & 16.4 \\
\hline 5 人 & 41 & 15.0 & 4 人 & 53 & 19.3 \\
\hline 6 人 & 47 & 17.1 & 5 人 & 50 & 18.2 \\
\hline 7 人 & 57 & 20.8 & 6 人 & 44 & 16.1 \\
\hline 8 人 & 52 & 19.0 & 7 人 & 31 & 11.3 \\
\hline 9 人 & 25 & 9.1 & 8 人 & 11 & 4.0 \\
\hline 10 人 & 20 & 7.3 & 9 人 & 7 & 2.6 \\
\hline 11人 & 1 & 0.4 & 10 人 & 8 & 3.0 \\
\hline 12 人 & 3 & 1.1 & 11人 & 3 & 1.1 \\
\hline 13 人 & 0 & 0 & 12 人 & 0 & 0 \\
\hline 14人 & 1 & 0.4 & 13人 & 3 & 1.1 \\
\hline 無回答 & 1 & 0.4 & 無回答 & 1 & 0.4 \\
\hline 計 & 274 & 100.0 & 計 & 274 & 100.0 \\
\hline
\end{tabular}

比較して多かった（表 3 ）。

\begin{tabular}{|l|c|}
\hline & 自転車 \\
\hline 徒歩, 64 & 35 \\
\hline \multicolumn{2}{|l|}{} \\
\hline
\end{tabular}
バイク, 0.4

車, 0 その他, 1

0

50

$100(\%)$

図 2 通学手段

\section{2. 通学手段}

“学校まで何で来ますか?”の設問に対して, 徒歩 (64\%) や自転車 (35\%) で通学する览童が多かった。 また, バイクで通学する児童は $0.4 \%$ と少なく, 車で通学 する児童はいなかった（図 2 )。

\section{1 日の食生活について}

1 日の食生活について調査した結果を図 3 に示した。 
1.1日の食事は何食ですか？

\begin{tabular}{|l|lll|}
\hline \multicolumn{2}{|l|}{ 1食以下, 0 } \\
\hline 2食, 39 & 3食以上, 61 & \\
\hline & & & \\
\hline
\end{tabular}

2. 1日の食事に満足していますか?

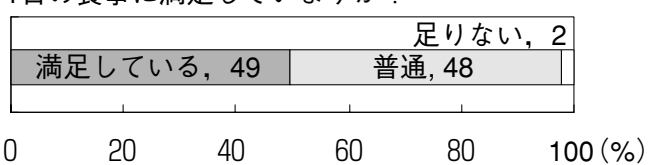

3.1日の食事で一番量が多いのはいつですか?

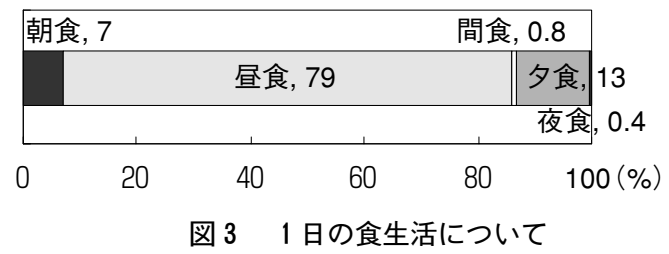

1 日の食事回数は “ 3 食以上”が $61 \%$ と多く, “ 2 食” が39\%，“1 食以下”は $0 \%$ であった。1 日の食事への 満足度は“満足している”が $49 \%$, “普通” $448 \%$, “足

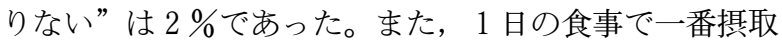
量が多いのは “昼食”で $79 \%$ と多く, 次に“夕食”が 13 \%,“朝食”が $7 \%$ あ゙あた。

\section{4. 食品群別の摂取頻度と体調}

食品群別の摂取頻度を図 4-1に示した。野菜を食べ る頻度は, “毎日”が49\%, “時々”が47\%であった。果 物を食べる頻度は “毎日”が $12 \%$, “時々”が $82 \%$ ，魚 を食べる頻度は“毎日” $69 \%$ ，“時々”30\%，肉を食べ る頻度は“毎日” $12 \%$, “時々” $83 \%$, また，乳製品を 食べる頻度は“毎日” $0 \%$ ，“時々” 81\%であった。

体調（図 4-2）について, “頭痛” と“腹痛” の頻 度について調查したところ, “頭痛”は“いつも痛い” が $7 \%$, “時々痛い”が $88 \%$ であった。“腹痛”は“いつ も痛い”が $4 \%$, “時々痛い”が $91 \%$ であった。

\section{5. アンケート調査前日の食事と生活活動および調査当} 日の体調について

調査項目として“前日の食事”, “前日の食事の内容”, “前日の活動”, “アンケート調查当日の体調”の 4 項目 について設問した（図 5-1〜 4)。前日の食事拱取状 況についての調査では, “昼食” 93\% と多く, ほとんど の児童が昼食を取っていた。その他は “朝食” 79\%， “間食” 56\%，“夕食” 31\%であった。前日に食べたもの を食品群別に見ると，たんぱく質の “魚”が92\%，炭水 化物の “ご飯”が $88 \%$ と多く，“野菜” $68 \%$ ，“菓子” 60 \%であった。前日の生活活動については “運動をした” が14\%，“仕事をした”が $97 \%$ ，“遊んだ”が88\%，“勉 強した”が95\%，“よく眠れた”が95\%であった。調査 当日の体調については “健康だと思う”が60\%, “虫歯 がある”が57\%, “便秘”が $5 \%$, “下痢”が13\%, “食
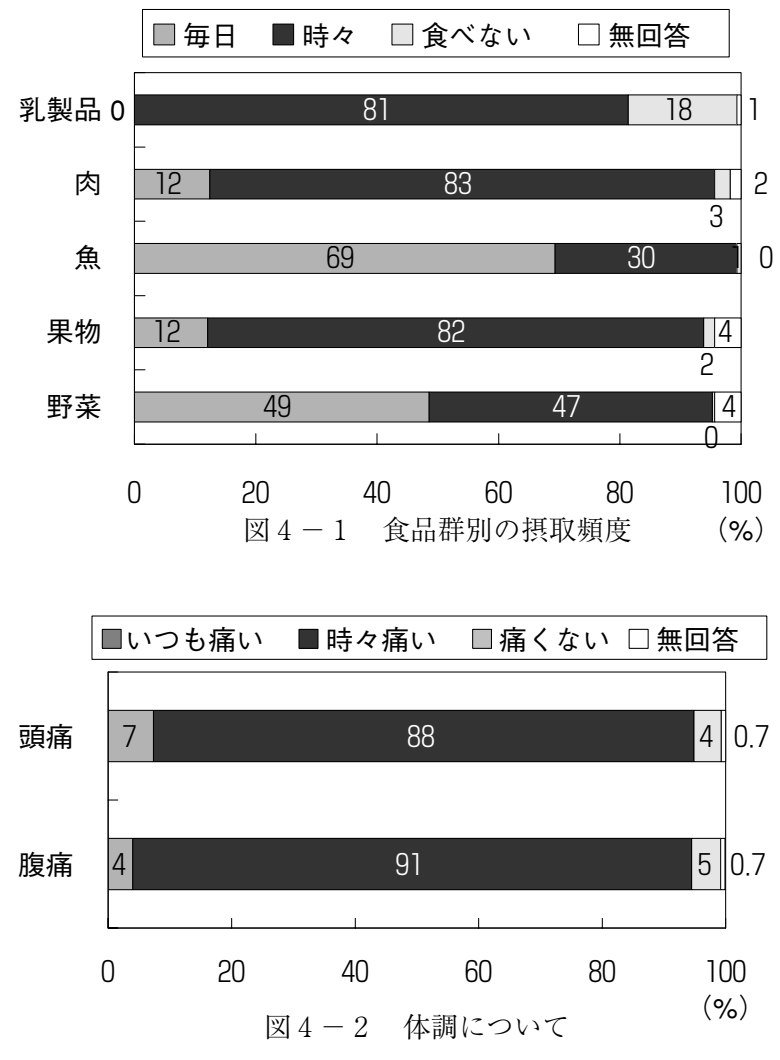

図4 食品群別の摂食頻度と体調

欲がある”が93\%であった。

6. WFP 支援の給食（朝食）について

WFP 支援の給食のメニューはニシンの缶詰スープ， 緑豆混ぜご飯である（写真 1 )。給食 1 人分は米 $(100 \mathrm{~g})$, 緑豆 $(40 \mathrm{~g})$, ニシンの大豆油缶詰 $(20 \mathrm{~g})$, 塩 $(3 \mathrm{~g})$, パーム油 $(9 \mathrm{~g})$ でエネルギー計算されている。

給食（朝食）についてのアンケート調査結果を図 6 1 ～ 7 に示した。“給食（朝食）を食べますか?”の設 問では, 給食を摂取するかについて, “毎日食べる”が $45 \%$, “時々食べる”が $52 \%$, “食べない”が $1 \%$ であっ た。給食がない日に朝食を摄取するかについて，“毎日 食べる”が36\%, “時々食べる”が59\%, “食べない”が $4 \%$ で，給食がない日は朝食を拱取しない児童が多かっ た。“給食または朝食の量”についての設問では, 給食 の量は “多い” $5 \%$, “普通” 93\%, “少ない” $1 \%$ であ った。給食がない日の朝食の量は “多い” $9 \%$, “普通” 80\%，“少ない” $9 \%$ であった。“給食または朝食は美味 しいですか?”の設問に対して給食は“美味しい”38\%， “普通” $61 \%$, “まずい” $1 \%$ であった。給食がない日の 朝食は “美味しい” $42 \%$, “普通” $55 \%$, “まずい” $3 \%$ であった。“給食がない日，どこで朝食を食べますか?” の設問に対して “家”が $84 \%$ と多く, “学校の売店” 10 \%, “市場” 5 \%であった。“家の朝食は給食と比べてど うですか?”の設問に対して，量は“多い”30\%，“同 じ”70\%,“少ない” 0.7\%。味は“美味しい” $8 \%$ ， “普通” 86\%, “まずい” 6\%であった。“給食が好きで 
カンボジア農村部における小学生の食生活
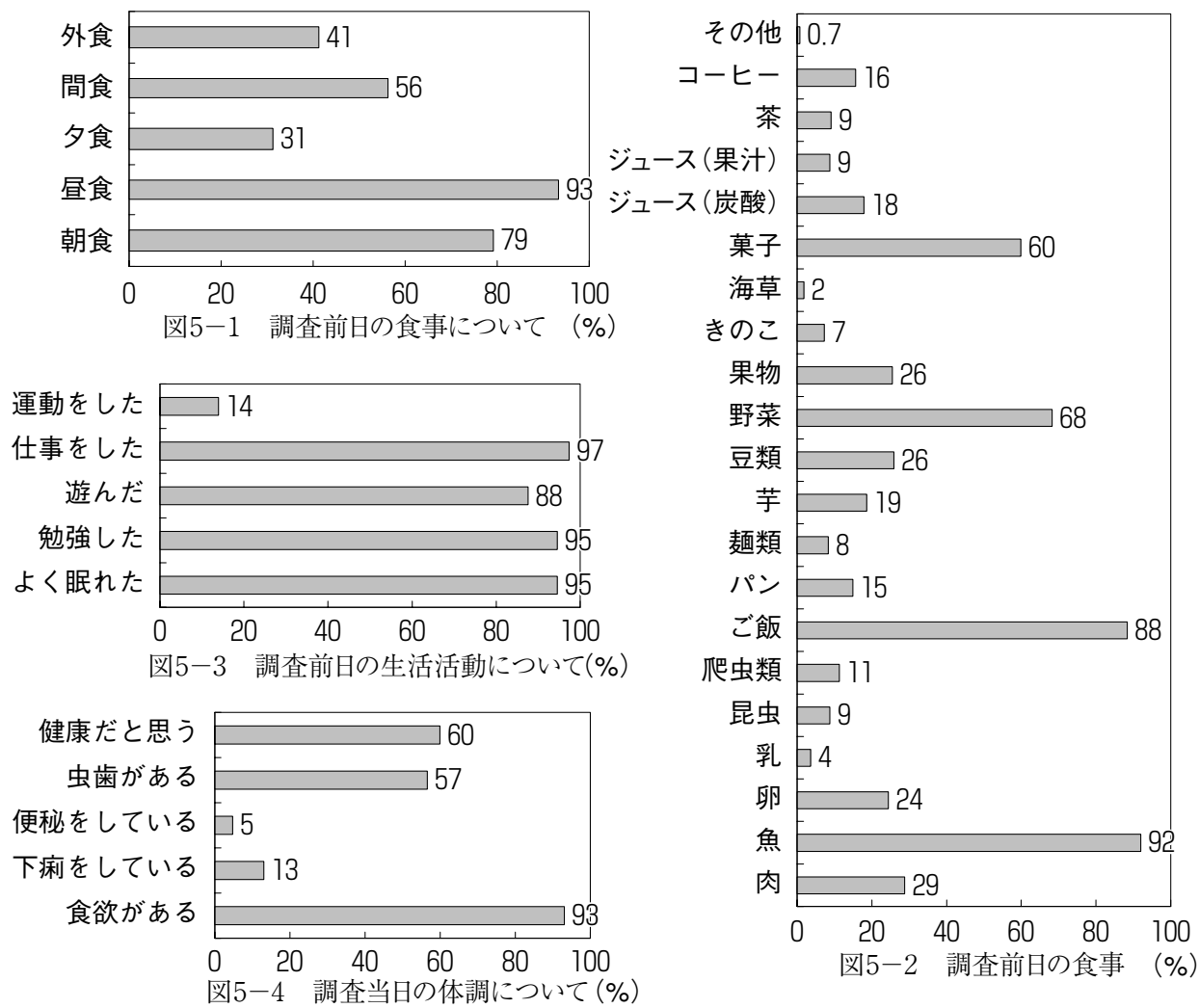

図 5 アンケート調査前日の食事と生活活動および調査当日の体調について

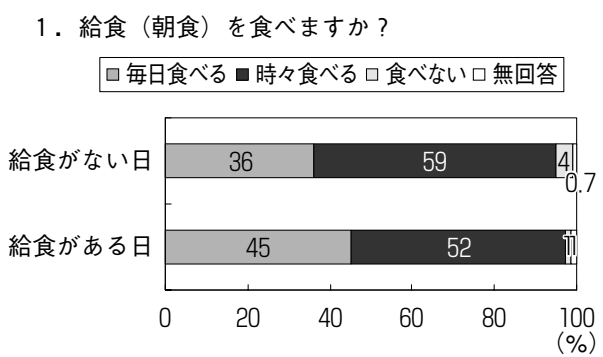

2. 給食 (朝食) の量は?

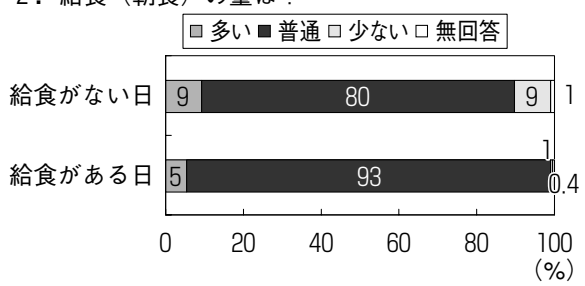

4.給食がない日、どこで朝食を食べますか？

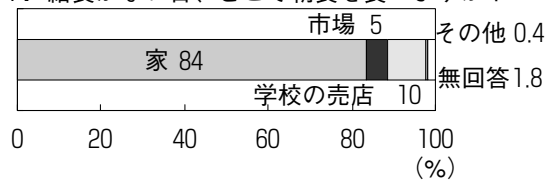

5. 家の朝食は給食と比べてどうですか？

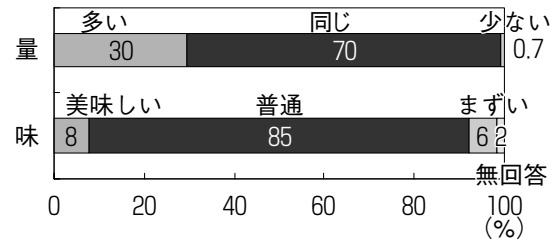

6. 給食が好きですか?

3. 給食 (朝食) は美味しいですか?
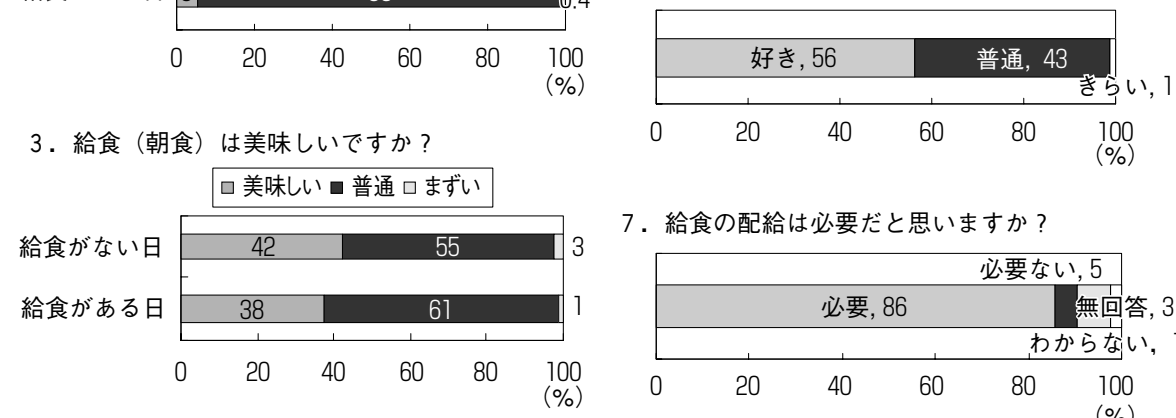

7. 給食の配給は必要だと思いますか?

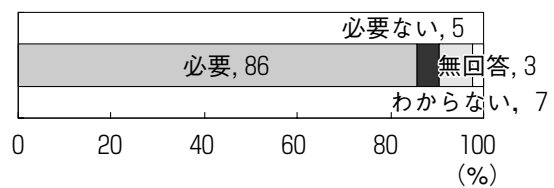

図 6 給食と朝食について 

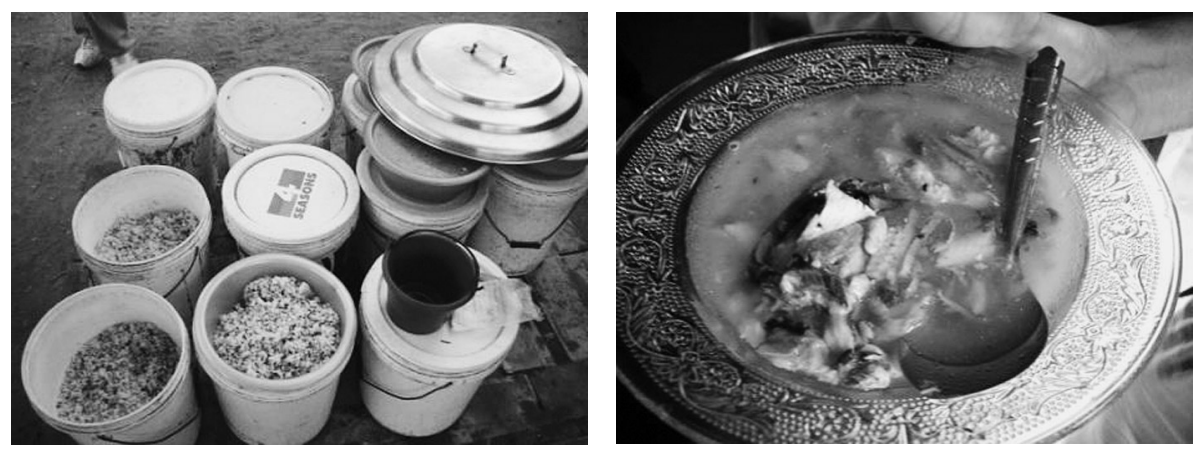

写真 1 WFP 支援の給食

すか?”の設問に “好き” $56 \%$,”普通“ $43 \%$,”嫌い “1\%であった。“給食は必要だと思いますか?”の設問 に“必要” 86\%, “必要ない” $5 \%$ で給食を必要だと思 っている児童が多かった。

\section{7. 身体測定結果と体格}

カンボジアの小学生の身体状況を把握するために, 食 生活調査を行った小学生を対象に身長と体重の測定を行 った。その結果を表 4 に示した。日本人の体格と比較す るために, 表 5 に平成15年厚生労働省国民栄養調査結果 より日本人の身長と体重を示した。年齢 $9 \sim 16$ 歳のカン ボジア人と日本人の男女別の身長と体重を各年齢別に比 較したところ，どの年齢でも男女共にカンボジア人の身 長は低く，体重も少なかった。調査したカンボジア人 13 歳男子の平均身長が $139.2 \mathrm{~cm}$, 平均体重が $28.3 \mathrm{~kg}$ であ
ったのに対して，同じ年齢の日本人男子の平均身長は $159.3 \mathrm{~cm}$, 平均体重は50.9kg で, 身長差は $20.1 \mathrm{~cm}$, 体 重差は $22.6 \mathrm{~kg}$ あった。カンボジア人 13 歳女子の平均身 長が $143.0 \mathrm{~cm}$, 平均体重が $32.1 \mathrm{~kg}$ であったのに対して, 同じ年歯令の日本人女子の平均身長は $155.2 \mathrm{~cm}$, 平均体重 は $46.3 \mathrm{~kg}$ で, 身長差は $12.2 \mathrm{~cm}$, 体重差は $14.2 \mathrm{~kg}$ あっ た。特に女子より男子の方が日本人との体格の差は大き い傾向がみられた。

表 6 に身長と体重から算出したローレル指数（100以 下：やせすぎ，101〜115：やせぎみ, 116〜144: 標準, 145〜159：太りぎみ，160以上 : 太りすぎ）と“自分の 体格についての意識”についてのアンケート調査結果を 示した。まず，ローレル指数から体格を検討してみると， 男子の $80 \%$ ( 84 人 $/ 105$ 人), 女子の $71 \%$ (106人 / 149 人 $)$

表 4 カンボジア人の身長と体重

\begin{tabular}{|c|c|c|c|c|c|c|c|c|c|c|}
\hline \multirow[b]{3}{*}{ 年齢 } & \multicolumn{5}{|c|}{ 男 } & \multicolumn{5}{|c|}{ 女 } \\
\hline & \multirow[b]{2}{*}{ 数 } & \multicolumn{2}{|c|}{ 身長（cm） } & \multicolumn{2}{|c|}{ 体重（kg） } & \multirow[b]{2}{*}{ 数 } & \multicolumn{2}{|c|}{ 身長（cm） } & \multicolumn{2}{|c|}{ 体重（kg） } \\
\hline & & 平均値 & $\begin{array}{l}\text { 標隻 } \\
\text { 偏差 }\end{array}$ & 平均値 & $\begin{array}{l}\text { 標準 } \\
\text { 府差 }\end{array}$ & & 平均值 & $\begin{array}{l}\text { 標準 } \\
\text { 偏差 }\end{array}$ & 平均值 & $\begin{array}{l}\text { 標準 } \\
\text { 偏差 }\end{array}$ \\
\hline 9 歳 & 7 & 126.6 & 4.3 & 22.1 & 2.5 & 12 & 127.3 & 7.3 & 24.8 & 6.7 \\
\hline 10歳 & 17 & 132.9 & 8.9 & 26.7 & 5.5 & 25 & 130.3 & 7.6 & 24.3 & 4.5 \\
\hline 11歳 & 11 & 131.5 & 1.6 & 24.6 & 2.2 & 28 & 132.7 & 5.9 & 26.0 & 4.8 \\
\hline 12歳 & 24 & 138.1 & 7.3 & 28.5 & 5.4 & 33 & 139.5 & 8.8 & 29.5 & 6.9 \\
\hline 13歳 & 19 & 139.2 & 5.8 & 28.3 & 4.5 & 32 & 143.0 & 8.2 & 32.1 & 6.4 \\
\hline 14歳 & 21 & 147.2 & 8.7 & 33.5 & 6.3 & 16 & 142.8 & 6.2 & 32.0 & 6.3 \\
\hline 15歳 & 10 & 148.3 & 10.5 & 33.8 & 8.0 & 1 & 140.3 & - & 40.5 & - \\
\hline 16歳 & 6 & 149.6 & 7.5 & 37.0 & 7.4 & 3 & 151.1 & 14.9 & 39.3 & 12.7 \\
\hline
\end{tabular}

表 5 日本人の身長と体重（平成15年厚生労働省国民栄養調査結果より) $\left.{ }^{4}\right)$

\begin{tabular}{|c|c|c|c|c|c|c|c|c|c|c|}
\hline \multirow[b]{3}{*}{ 年齢 } & \multicolumn{5}{|c|}{ 男 } & \multicolumn{5}{|c|}{ 女 } \\
\hline & \multirow[b]{2}{*}{ 数 } & \multicolumn{2}{|c|}{ 身長（cm） } & \multicolumn{2}{|c|}{ 体重（kg） } & \multirow[b]{2}{*}{ 数 } & \multicolumn{2}{|c|}{ 身長（cm） } & \multicolumn{2}{|c|}{ 体重（kg） } \\
\hline & & 平均値 & $\begin{array}{l}\text { 標準 } \\
\text { 偏差 }\end{array}$ & 平均値 & $\begin{array}{l}\text { 標準 } \\
\text { 偏差 }\end{array}$ & & 平均値 & $\begin{array}{l}\text { 標準 } \\
\text { 偏差 }\end{array}$ & 平均値 & $\begin{array}{l}\text { 標準偏差 } \\
\text { 㳯 }\end{array}$ \\
\hline 9 歳 & 52 & 132.9 & 5.8 & 29.9 & 4.7 & 44 & 133.4 & 6.5 & 30.1 & 6.2 \\
\hline 10歳 & 60 & 139.8 & 6.0 & 34.9 & 7.2 & 48 & 139.0 & 6.4 & 33.4 & 6.5 \\
\hline 11歳 & 53 & 143.7 & 8.0 & 37.9 & 6.9 & 48 & 144.3 & 6.8 & 36.5 & 7.4 \\
\hline 12歳 & 42 & 151.3 & 9.5 & 45.8 & 9.7 & 51 & 152.0 & 5.3 & 43.3 & 6.7 \\
\hline 13歳 & 43 & 159.3 & 8.1 & 50.9 & 11.3 & 46 & 155.2 & 4.4 & 46.3 & 7.2 \\
\hline 14歳 & 40 & 162.1 & 7.8 & 52.9 & 10.1 & 37 & 156.9 & 5.5 & 51.1 & 9.2 \\
\hline 15歳 & 38 & 167.7 & 5.1 & 58.4 & 12.0 & 48 & 157.1 & 4.4 & 50.4 & 7.8 \\
\hline 16歳 & 43 & 170.3 & 6.5 & 59.2 & 8.4 & 16 & 158.0 & 4.5 & 51.6 & 9.8 \\
\hline
\end{tabular}




\begin{tabular}{|c|c|c|c|c|c|c|c|c|c|c|c|c|}
\hline \multirow[b]{3}{*}{$\begin{array}{l}\text { 自分の体格につ } \\
\text { いての意識 }\end{array}$} & \multicolumn{12}{|c|}{ ローレル指数 } \\
\hline & \multicolumn{6}{|c|}{ 男 } & \multicolumn{6}{|c|}{ 女 } \\
\hline & $\begin{array}{l}\text { やせ } \\
\text { すぎ }\end{array}$ & $\begin{array}{l}\text { やせ } \\
\text { ぎみ }\end{array}$ & $\begin{array}{l}\text { 標 } \\
\text { 準 }\end{array}$ & $\begin{array}{l}\text { 太り } \\
\text { ぎみ }\end{array}$ & $\begin{array}{l}\text { 太り } \\
\text { 导ぎ }\end{array}$ & 計 & $\begin{array}{l}\text { やせ } \\
\text { すぎ }\end{array}$ & $\begin{array}{l}\text { やせ } \\
\text { ぎみ }\end{array}$ & $\begin{array}{l}\text { 標 } \\
\text { 準 }\end{array}$ & $\begin{array}{l}\text { 太り } \\
\text { ぎみ }\end{array}$ & $\begin{array}{l}\text { 太り } \\
\text { すぎ }\end{array}$ & 計 \\
\hline やせている & 4.8 & 2.8 & 0 & 0 & 0 & 7.6 & 4.0 & 7.4 & 0.7 & 0 & 0 & 12.1 \\
\hline 少しやせている & 5.7 & 13.3 & 4.8 & 0 & 0 & 23.8 & 6.7 & 7.4 & 5.3 & 0 & 0 & 19.4 \\
\hline 普通 & 7.6 & 30.5 & 7.6 & 0 & 0 & 45.7 & 8.7 & 30.2 & 11.4 & 0.7 & 0.7 & 51.7 \\
\hline 少し太っている & 3.8 & 8.6 & 4.8 & 0 & 0 & 17.2 & 0.7 & 4.7 & 6.7 & 0 & 0 & 12.1 \\
\hline 太っている & 1.0 & 1.9 & 2.8 & 0 & 0 & 5.7 & 0.7 & 0.7 & 3.3 & 0 & 0 & 4.7 \\
\hline 計 & 22.9 & 57.1 & 20.0 & 0 & 0 & 100.0 & 20.8 & 50.4 & 27.4 & 0.7 & 0.7 & 100.0 \\
\hline
\end{tabular}

がやせすぎ，またはやせぎみであった。また，標準は男 子の $20 \%$ (21人/ 105 人), 女子の $27 \%$ (41人/ 149 人) であった。男子は太りぎみ，または太りすぎが $0 \%$ に対 して，女子は $1.4 \% （ 2$ 人/ 149 人）いた。しかし，自分 の体格についての意識調査では，やせすぎ，またはやせ ぎみの体型にも関わらず，普通と答えた児童が多かった。

\section{考察}

調査を行ったササースダム小学校は児童数 1,163 人 (男子児童 632 人, 女子児童 531 人), 教員数 23 名の小学校 である。農村地帯にあり, 大半は農家である。調査期間 の 2 月〜 3 月は乾季で，井戸や池が枯れ，生活に必要な 水を確保することも困難である。また生活のために父親 が出稼ぎに出かける家庭も多く, 経済的には豊かではな い。

調査対象の家族の人数は平均 6.87 人で，日本の家族の 人数の平均 2.68 人と比較して多かった。

日本の小学校の学区域は約 $2 \mathrm{~km}$ 以内であるのに対し, シェムリアップ州プク郡内の小学校の区域は約 $5 \mathrm{~km} \sim$ $10 \mathrm{~km}$ である。児童は徒歩または自転車で通学していた。

食糧生産が困難である乾季でのシェムリアップ州プク 群内の小学生において 1 日の食事摂取回数は“ 3 食以上” が $61 \%$, “ 2 食” が $39 \%$ と比較的食事回数も多く，また 1 日の食事回数に満足している児童も約半数の $49 \%$ であ った。1 日の食事で 1 番摂食量が多いのは昼食で $79 \%$ と 高值を示したが，これはフランス統治時代の西欧の食習 慣の影響を受けているのではないかとも考えられる。

食品群別の摂取頻度について豚や鶏などの食肉類を食 べる頻度は魚介類と比較すると低かった。魚介類を食べ る頻度が多い理由は, 近くの池や川で淡水魚が獲れるか らである。しかし，乾季になると池や川の水量が減少し， 漁獲量も少なく，小魚を家族みんなで分け合って食べて いるため一度に食べる量は少ない。乳製品の摂取頻度が 低い要因としては, プク群のササースダムの農村地帯で は乳牛を飼育しておらず，そのため乳類の摂食習慣があ まりない。また乳製品の販売も少ないことによると考え られる。野菜を食べる頻度は高いが，野菜類を栽培して いる家庭は少なく，近くの林などで取った木の葉や食用
の雑草などをスープに入れて食べている程度の家庭もあ った。このため食物繊維やビタミン類の摂取面を考慮す ると野菜栽培の農業技術指導などを行うことが多くの野 菜摂取に有効と考えられる。

アンケート調査前日の昼食の摂取は $93 \%$ ，朝食 $79 \%$ で あった。調査前日の食事について，児童のほとんどの家 庭では稲作を行っており, 炭水化物としてのエネルギー 源である米食の摂取率は高い。主食であるご飯と魚を除 く副食は摂食率が全般的に低かった。その要因は自給自 足の生活と貧しい経済状況が反映されていると考えられ る。児童が健康に発育するためにはバランスの摂れた栄 養摂取は重要であり, 食肉類, 乳製品などを食べる食習 慣の環境を増やすことが必要である。

生活活動についてのアンケート調査では“運動をした” は14\%と少なかったが，“仕事をした”が97\%と多く， 児童は農業や家庭内の手伝いをよくしている。をた， “遊んだ”が88\%でほとんどの児童が屋外で遊んでいる。

体調について“虫歯がある”が $57 \%$ と半数以上であっ た。小学校では歯磨きをする習慣がないため虫歯の児童 が多かった。今後, 栄養教育だけでなく, 歯科衛生に関 する教育も必要であると考えられる。

児童の食べている食品群の摂食状況および摂食量を把 握するために, WFP 支援による朝食の学校給食と家庭 の朝食を比較検討した。その結果, 学校給食のない日に 家庭の朝食を食べる児童は“毎日食べる”が36\%と低か った。むた，家庭の朝食と学校給食の摂食量には大きな 差は見られなかった。給食は毎日同じメニュー（ニシン の缶詰スープ, 緑豆混ぜご飯）であり，1人分は米 $(100 \mathrm{~g})$, 緑豆 $(40 \mathrm{~g})$, ニシンの大豆油缶詰 $(20 \mathrm{~g})$, 塩 ( $3 \mathrm{~g})$ およびパーム油（9g) で約650kcal とエネルギー 換算され, たんぱく質, 脂質, 炭水化物がバランスよく 摂取できるようになっている。しかし, 児童の食器のサ イズは揃っておらず，また年齢差もあり，給食の摂取量 は児童によって異なっていた。しかし，給食がない日は 朝食を時々食べる児童が多いこと, また, その量や味に ついて，ほとんどの児童が満足していることから WFP 支援の給食は重要であると考えられる。WFP の学校給 食プログラムは 3 年間で終了する予定で, 給食の必要性 
を感じている児童は $86 \%$ と多い。このことから, WFP の学校給食支援終了後も児童が充分な食事を拱れるよう 継続的な学校給食提供の施策が必要である。

身体測定の結果では, カンボジア人と同じ年齢の日本 人の身長と体重を比較したところ, 男女ともにササース ダム小学校の児童の方が身長は低く, 体重は軽かった。 身長と体重から算出したローレル指数の結果から, 男子 の $80 \%$, 女子の $71 \%$ がやせおり, 栄養不足が示唆され た。また, 自分の体格についての意識調査では, やせて いるにも関わらず，“普通”と答えた児童が多かった。 このことは児童の体格に対する意識を改善する必要性を 示している。

カンボジアの食料事情は, 都市部のシェムリアップ市 内の市場には椂々な種類の肉類, 魚介類, 野菜抢よび果 物類があり, 食材は豊富に揃っていた。しかし, 本調査 の結果から, 農村部では米や魚以外の食料が充分ではな い実態が明らかとなった。児童が健康的に発育するため にはバランスの取れた栄養摂取は非常に重要であり，一 日の規則正しい食生活が可能となるような施策の必要性 が示唆された。また，その施策に含まれる保健教育を通 して人々が健康の大切さを学ぶことが, カンボジアの農 村地帯の家庭における食生活の改善に結びつくと思われ る。

\section{要 約}

カンボジアの農村地帯にある小学校の児童の日常にお ける食生活と健康状態について調查 (2006年 2 月～ 3 月) を行った。調查対象は 9 歳 16歳の小学生 274 人 (男子 119人，女子 155 人）でる。その結果は以下の通りである。 (1) 1 日の食事摂取回数は “ 3 食以上”が $61 \%$, “ 2 食” が39\%であり，その中で掑食量が多いのは昼食で79\%
であった。をた, 食品群別の調査では, 食肉類, 乳製 品などのたんぱく質食品の摂取率が低かった。

(2) 身長と体重より算出したローレル指数の結果から, 男子の $80 \%$,女子の $71 \%$ がやせていた。同年齢の日本 人の身長抢よび体重と比較すると, 男女ともカンボシ アの農村地帯の小学生の方が低值であった。また, 自 分の体格についての意識調査では, やせているにも関 わらず，“普通”と答えた児童が多かった。

これらの結果からカンボジアの農村地帯の児童の栄養 不足が示唆された。児童の発育・発達のためには, バラ ンスの取れた栄養拱取が重要な課題であり, そのための 施策が必要であることが明らかとなった。

\section{謝 辞}

本調査は広島県カンボジア復興支援プロジェクトおよ び独立行政法人国際協力機構（JICA）の協力により遂 行できました。ここに感謝の意を表します。また, 本調 査にご協力いただきました皆様に心よりお礼申し上げま す。

\section{文献}

1）吉崎基弥, 青山温子, 永井真理, 小林明子 : カンボジア における身体障害者支援の現状と課題, 国際保健医療, 21, 43〜 51 (2006)

2）池田昌代, 加藤みゆき, 長野宏子, 阿久澤さゆり, 大森 正司：カンボジアに抢ける発酵米麺の製造方法と食し方に ついて, 日本家政学会誌，56，827〜833（2005）

3）森枝卓士，世界の食文化 4 ベトナム・カンボジア・ラ オス・ミャンマー, 社団法人農山漁村文化協会 (2005)

4）厚生労働省健康 ·栄養情報研究会 : 国民栄養の現状, 平 成15年厚生労働国民栄養調査結果，第一出版（2006） 